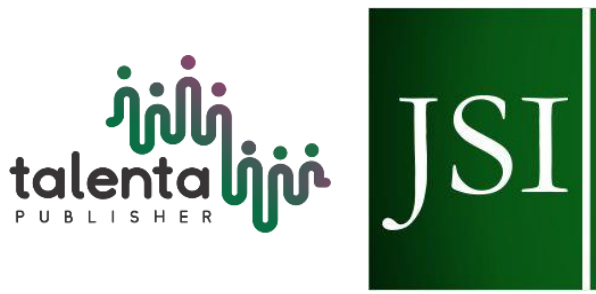
Journal of

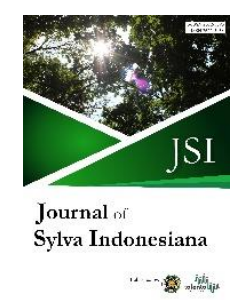

\title{
Effects of Gamma Ray Irrad iation to Induce Genetic Variability of Teak Planlets (Tectona grandis Linn. F.)
}

\author{
Ahmad Parlaongan $^{1 *}$, Supriyanto $^{2}$, and Arum Sekar Wulandari ${ }^{2}$ \\ ${ }^{1}$ Department of forestry, Faculty of Science and Technology, Universitas Muhammadiyah Jambi, Jambi, \\ Indonesia \\ ${ }^{2}$ Departement of Silviculture Tropica, Faculty of Forestry, IPB University (Bogor Agricultural \\ University), West Java, Indonesia
}

\begin{abstract}
Teak planlets (Tectona grandis) of Salomon clones were irradiated by gamma rays to induce genetic variability for growth improvement. The objectives of this research were to analyze the radiosensitivity of $\mathrm{T}$. grandis Salomon clones by gamma ray irradiation and to analyze the genetic variations using Random Amplified Polymorphic Deoxyribonucleic Acid (RAPD). For those purposes, teak planlets were irradiated using gamma rays at 5 different dosages, those were $0 \mathrm{~Gy}, 10 \mathrm{~Gy}, 20 \mathrm{~Gy}, 30 \mathrm{~Gy}$, and $40 \mathrm{~Gy}$. Lethal doses50 (LD50) and reduced doses50 (RD50) were obtained using Curve-fit Analysis. Furthermore, the irradiated planlets were subcultured on medium MS +0.1 kinetin (M1V0) the surviving M1V0 plantlets were multiplied to MS + 0.1 kinetin, so it is obtained the M1V1 generation. Genetic variation of the mutant was molecularly analyzed using RAPD methods and the variability was calculated using Analysis of Molecular Variance (AMOVA). Results of this research showed that lethal doses50 (LD50) and reduced doses50 (RD50) values were obtained at $24.5 \mathrm{~Gy}$ and $7.85 \mathrm{~Gy}$, respectively. It includes genomes of small size and a small number of genomes. The genetic variation of mutant individuals in among and within the treatment of gamma irradiation was $16 \%$ and $84 \%$ according to AMOVA. It means that the dominant effect of genetic material caused genetic variation in mutant M1V1 generations. This dominance of genetic material could be caused by the response combination of tissue culture treatment and genetic factors that had the potency to be used as materials to select desired clones in the next stage.
\end{abstract}

Keyword: Genetic Variation, Mutant, Radiosensitivity, RAPD, Teak (Tectona grandis)

Received 22 April 2021 | Revised 4 August 2021 | Accepted 6 October 2021

\section{Introduction}

Teak (Tectona grandis) is one of the most valuable timber trees for the material of wood construction and carpentry. Naturally, inherited desirable teak timber characteristics have remarkable physical and mechanical properties, particularly strength II grades, durability I grades, workability, and aesthetic features. These characteristics have been led to the

\footnotetext{
*Corresponding author at: Department of forestry, Faculty of Science and Technology, Universitas Muhammadiyah Jambi, Jambi, Indonesia

E-mail address: a.parlaongan@gmail.com
} 
consequence, with a short shortage of supply (teak timber production), the demand for teak timber increases [1]. The total requirement for teak timber in Indonesian and international markets reaches \pm 1.5 -2.5 million $\mathrm{m} 3$ per year, of which at least $90 \%$ is harvested in India, Indonesia, and Myanmar [2]. However, this timber supplies currently available only $\pm 20 \%$ $(4.11 .893 \mathrm{~m} 3)$ of the volume of teak timber used in Indonesia, resulting from a market gap in demand at \pm 1.1 million $\mathrm{m} 3$ [3]. The decrease in site quality had a negative effect to determine the growth and development of plants; it is related to the quality and quantity of fertilization proportion blossoms, which is reflecting the decrease in productivity. Low genetic diversity of teak is caused by the quantitatively limited availability of natural germplasm among existing plants since it is an exotic plant [4] and has open pollination system (chasmogamy) [5]. Plant improvement requires high genetic diversity to obtain an extended opportunity of desired trait combinations according to the strategy of tree breeding.

Plant breeding technique is used to increase plant productivity through the utilization of genetic diversity and develop new varieties in certain specific traits [6]. Teak breeding has been established by cross-breeding (hybridization) [7], mutation breeding [8], and genetic transformation [9]. The mutation technique is commonly most popular on strategies for breeding to induce mutants and increase plant production, because it could induce recessive genes [10]-[11] in several new generated mutants.

Gamma rays as a physic mutation type technique are widely used to increase genetic variation. This mutation technique in vitro culture, can be able to induce in a short time and more easily created a stable mutant, which is a superior genetic and a desirable phenotypic appears to obtain individual lines with a specific characteristic to improve productivity [12] compared to ex Vitro and field experiment mutation breedings. Mutants result from interactions between free radicals generated by gamma rays with water substances in the vacuole, causing morphological, anatomical, biochemical, and physiological changes [13]. The frequency of mutation also serves as an index of radiosensitivity, which is influenced by mutagenic effectiveness (dose of gamma rays irradiation) and efficiency explants (phases, size, and thickness) [14]. Gamma rays at low doses (0-10 KGy) and the use of plant parts that are actively dividing; such as meristem cells are important factors for the successful induction of genetic variation [15]. The appropriate utilization of irradiation dose may be determined by genome size, the smaller genome size the lower dose needed for irradiation, as well as for the larger genome size, the use of higher doses of irradiation. The teak genome has 36 chromosomes with the size of $0.94 \mathrm{Pg}$ (868.5 Mbp) [16], including small size chromosomes. In Vitis vinifera $(n=19 ; \mathrm{V}$ genome $=475 \mathrm{Mbp})$, with explant dormant buds have used a dose of gamma rays at 25-35 Gy; Persea americana $(2 n=24$; $\mathrm{V}$ genome $=907 \mathrm{Mbp}$ ), with explant zygotic embryo, is irradiated using a dose of gamma rays at 25 Gy [17]. Teak plantlets have potentially been used as explants (plant materials) for irradiation because the multiplication of teaks has been carried through micropropagation 
techniques [18]. Planlet requires a relatively shorter time for producing mutant compared to other vegetative organs due to meristematic cell development.

Application of gamma ray irradiation on meristematic cells may develop a new genetic variation, the variation in which needs to detect the stability in any event expression of genetic variations arising among mutant generations [19]. Genetic variation is determined by radiosensitivity [20]. The plant radiosensitivity does not always affect the cells and DNA material [21]. Therefore, it is necessary to study the use of gamma ray irradiation on teak plantlets with various levels of dosages. Information on irradiation doses is very useful in studying teak growth in vitro and ex vitro conditions. Planlet of Post-irradiated generation or mother material1 vegetative1 generation (M1V1) may also be seen through morphological and genetic analysis using RAPD (Random Amplified Polymorphic DNA) to detect the genetic variation that has occurred as a result of gamma ray irradiation. The purpose of this study was to analyze the value radiosensitivity and genetic variation using the RAPD method on M1V1 mutants.

\section{Methods}

This research was carried out at the Tissue Culture Laboratory Forest Resource Conservation and Ecotourism (KSHE), Faculty of Forestry, Bogor Agricultural University. Gamma ray irradiation treatment was conducted at the Central Laboratory of Isotope and Irradiation Technology Applications (PATIR), National Nuclear Energy Agency (BATAN), and Laboratory of Molecular Genetics of Forest and Forestry for Analysis of genetic variation.

\subsection{Material Preparation Plant}

The teak planlets were cut into pieces using scissors with a single nodal segment before multiplication (M0V0). These were done in a petri dish, containing sterile distilled water to maintain osmotic balances and transpiration of plants, so that plants were not withered and stressed. M0V0 plantlets were further placed on medium MS containing $0.1 \mathrm{ppm}$ BAP +0.1 ppm kinetin [22] and incubated at room temperature at $24 \mathrm{oC}$ for 3 months. The light duration was $16 / 8$ hours (MIVI).

\subsection{Mutations Induced by Gamma Rays}

Mutation induction was mediated by gamma ray using irradiators Chamber Cobalt60 (60Co) in BATAN. Gamma ray irradiation was applied to planlets at 5 different dosages, which were 0 , 10, 20, 30, and $40 \mathrm{~Gy}$. Irradiated plantlets were transferred into new media MS0 (MS without hormone). The survived plantlets after irradiation were called M1V0 generations, whereas before irradiated planlets were called M0V0 generations. Each plantlets were cultured and observed in each culture bottle. The observed parameters were LD50, RD50, and the number of leaves. The data analysis was done using Curveexpert Software 1.3. The regression calculation 
model of LD50 and RD50 was Gaussian models, is a normal distribution curve with equation [23]:

$$
y=a^{\frac{-(x-b)}{2 c}}
$$

$\mathrm{LD}_{50}$ calculation was obtained from survived planlets after irradiation, incubated in media MS0 during 3 months and 16/8 hours light duration.

This study was arranged in a completely randomized design (CRD) in four replication. Each experimental unit consisted of 5 plantlets, so the total of planlets for irradiation treatment was 100 plantlets in M1V0 generations. Each bottle was planted by a single planlet and all irradiated planlet were observed. The data were analyzed and documented by photography for visualizing the development stages of plantlets.

\subsection{Multiplication of Teak Planlets Post-Irradiation}

After irradiation, planlets were multiplicated in MS medium $+0.1 \mathrm{ppm}$ kinetin that aimed to avoid chimera and diplontic selection phenomenon. It was called M1V1 generation. Multiplicated planlets were originated from teak plantlets of Solomon clones (M1V0) with a single nodal segment and the leaves cut in half to reduce transpiration. The M1V0 planlet length was around a single nodule segment and the leaves were cut in half to reduce transpiration. These were carried out in a Laminar Air Flow Cabinet (LAFC), sterilized using ultraviolet light for 1 hour, and with $70 \%$ ethanol.

\subsection{Genetic Analysis using RAPD}

DNA extraction was done using about 5 gram calli of planlets M1V1, selected randomly from 3 mutant planlets in each treatment. The protocol DNA of extraction was essentially a method of CTAB (Cetyl Trimethyl Ammonium Bromide) (modified by [24]) and amplified by RAPD (Table 1). The DNA banding pattern of electrophoresis results was interpreted in the form of a scoring system [25]. Scoring results were processed using Microsoft Excel software that comes with GenAlex 6.5, Version Popgen 1:32, and NTSYSpc Version 20.1d.

Table 1 RAPD primers used for amplification of Tectona grandis

\begin{tabular}{ccc}
\hline Primers & Sequence $\left(5^{\prime}-3^{\prime}\right)$ & Annealing $\left({ }^{0} \mathrm{C}\right)$ \\
\hline OPC-1 & TTCGAGCCAG & 37 \\
OPC-2 & GTGAGGCGTC & 37 \\
OPC-8 & TGGACCGGTG & 37 \\
OPC-9 & CTCACCGTCC & 37 \\
OPC- 10 & TGTCTGGGTG & 37 \\
\hline
\end{tabular}




\section{Results and Discussion}

\subsection{Radiosensitivity}

Radiosensitivity is used as an indicator of the quantitative effect of gamma rays [26], an indicator to determine the antioxidant activity of plant systems [27], and as a defense system of plants (defensive mechanism system) to gamma rays [28]. Radiosensitivity is also used as a parameter for assessing the effectiveness of mutations through physiological changes [29], as well as the growth and development of plants [30]. The variable sensitivity level is calculated based on the survival rate of planlets and height growth. The survival rate of planlet and planlet height growth are calculated based on the LD50 (Lethal doses50) and RD50 (Reduced doses50).

The survival rate of planlets depends on given irradiation doses, at a higher dose of irradiation caused the decrease of the plant viability [31]. The LD50 value of T. grandis planlets of salomon clone was 24.5 Gy (Figure 1A). In control, all planlets survived; however, there were 5 planlets contaminated by the fungus (Table 2). Gamma ray irradiation dose at 30 and 40 Gy reduced the survival rate of planlets by $80 \%$. These doses (30 and $40 \mathrm{~Gy}$ ) are categorized as high dose irradiation that affected the survival rate of planlets. High and low irradiation doses depended on biological responses both negative and positive correlations on plant material used. The increasing frequency of chromosomal damages was proportional to the irradiation doses, the increasing irradiation dose corresponded to increasing levels of chromosome damage; so it inhibited the plant survival [29], plant growth, and mitotic delays [32].

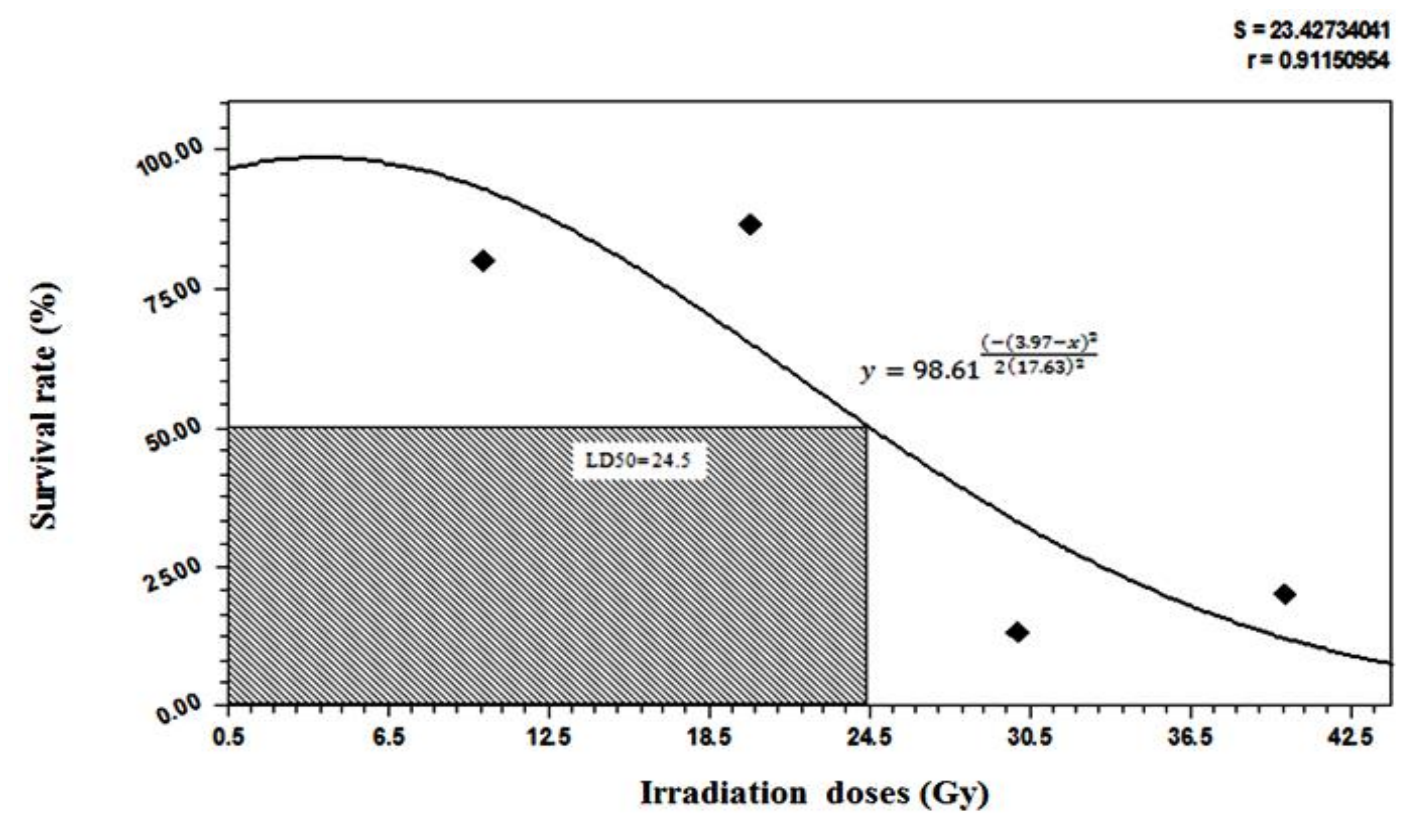

Figure $1 \mathrm{LD}_{50}$ of teak planlets in vitro conditions 


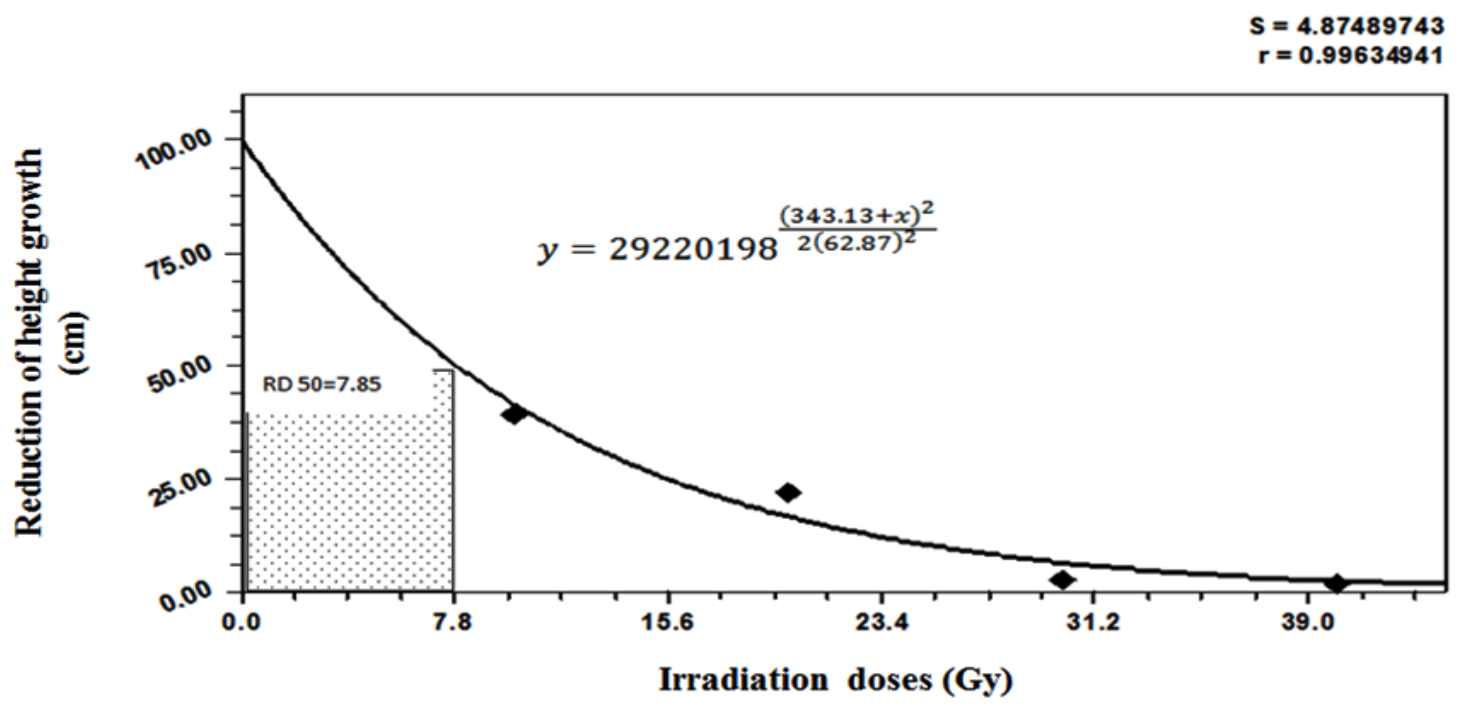

Figure $2 \mathrm{RD}_{50}$ of teak planlets of clones in vitro conditions

Table 2 Effect of irradiation on height growth and leaves number of teak plantlets in in vitro

\begin{tabular}{ccccccccc}
\hline $\begin{array}{c}\text { Doses } \\
(\mathrm{Gy})\end{array}$ & $\begin{array}{c}\Sigma_{\text {survival }} \\
\text { planlets }\end{array}$ & $\begin{array}{c}\Sigma_{\text {Contam }} \\
\text { inated } \\
\text { planlets }\end{array}$ & $\begin{array}{c}\mathrm{T} 0 * \\
(\mathrm{~cm})\end{array}$ & $\begin{array}{c}\mathrm{T} 1 * \\
(\mathrm{~cm})\end{array}$ & $\begin{array}{c}\Delta \mathrm{T}= \\
\mathrm{T} 1-\mathrm{T} 0\end{array}$ & $\begin{array}{c}\mathrm{N} 0 * \\
\text { Mean } \pm S D\end{array}$ & $\begin{array}{c}\mathrm{N} 1 * \\
\text { Mean } \pm \\
\text { SD }\end{array}$ & $\begin{array}{c}\Delta \mathrm{N}= \\
\mathrm{N} 1 *-\mathrm{N} 0 * \\
\text { Mean } \pm S D\end{array}$ \\
\hline 0 & 15 & 5 & 6.4 & 10.0 & 3.6 & $5.45 \pm 1.8$ & $7.60 \pm 1.7$ & $2.2 \pm 2.4$ \\
10 & 12 & 5 & 5.1 & 6.6 & 1.4 & $4.15 \pm 1.4$ & $6.15 \pm 1.3$ & $2.0 \pm 1.4$ \\
20 & 13 & 1 & 4.5 & 5.3 & 0.8 & $4.65 \pm 1.5$ & $5.60 \pm 1.9$ & $0.9 \pm 1.7$ \\
30 & 2 & 1 & 5.2 & 5.1 & 0.1 & $4.75 \pm 1.8$ & $3.80 \pm 1.2$ & $-0.9 \pm 2.0$ \\
40 & 3 & 0 & 5.2 & 5.3 & 0.07 & $4.65 \pm 0.9$ & $3.80 \pm 1.1$ & $-0.8 \pm 1.3$ \\
\hline
\end{tabular}

Notes: *T0: Height M0V0; T1: height M1V1; N0: number of leaves M0V0; N1: number of leaves M1V0

Value RD50 of teak planlet of Solomon clones in vitro was at 7.8 Gy. (Figure 2). Reduction of height growth (enthalpy) on M1V0 plantlets decreased at all irradiation treatments (Table 2). The dose of gamma ray irradiation at $10 \mathrm{~Gy}$ may reduce the activity of endogenous cytokinin hormone, it caused the growth of planlet goes slow down. Decreasing the amount of endogenous cytokines synthesis caused by protein synthesis either decreased or damage and physiological damage after irradiation [31].

Based on Table 2, enthalpy of leaves number M1V0 occurred after gamma ray irradiation with doses at 30 and $40 \mathrm{~Gy}$. The low enthalpy of leaves number may be caused by the dried and falt down leaves (senescences). It is possible to the doses of 30 and $40 \mathrm{~Gy}$ were able to subquentially increase glutathione compound [33], inhibit the synthesis of auxin hormone, and increase the hormone ethylene on leave plantlets.

\subsection{Genetic variation}

All M1V0's planlet were multiplicated in MS medium $+0.1 \mathrm{ppm}$ kinetin, had a different response. It depended on the dose of irradiation (Figure 3). In control, planlets grew normally, 
while irradiated planlets stimulated the occurrence of callus formation (callogenesis). At $10 \mathrm{~Gy}$, planlets formed calli and had fragile structure, small size, and brownish, while the irradiation doses of 20,30, and 40 Gy produced somatic embryogenic structure.

Morphological changes could not always be explained by genetic material changes [34]. PCRbased DNA marker techniques are used in determining the genetic relatedness and diversity [35]. RAPD is a dominant marker that is widely used for genetic mapping, analysis of mutants, and somaclonal variation during the culture period [36]. These markers were amplified genomic widely and randomly so that the RAPD primer used is not specifically required. There are many scientific papers about analysis for genetic relatedness and diversity using RAPD markers on Solanum tuberosum L. [37], Tectona grandis [38], Pinus kwangtungensis Chun ex Tsiang [39] Dendranthema grandiflora Tzvelev [40], and bamboo [41]-[42]. RAPD analysis using callus mutant M1V1 produced dendrogram shown in Figure 3.

The value of the genetic distance between the individual mutants and controls is shown in the dendrogram in Figure 4. The dendrogram is divided into three major clusters, reflecting the genetic variation among all mutant M1V1 individuals. Those are the first cluster consisted of individual control I and 10 Gray III. The second cluster is divided into two subclusters, namely subcluster 1 (control II, Control III, 20 Gy III, 20 Gy II, 30 Gy I, 30 Gy II, III 30 Gy, 40 Gy I, and 40 Gy III) and subcluster 2 (10 Gray I, 10 Gray II, and 20 Gy I), the genetic distance between subcluster 1 and subcluster 2 was 0.21 . The third cluster was in an individual of $40 \mathrm{~Gy}$ II and formed their group. The genetic distance between individual mutants and controls based on dendrogram ranged from $0-0.85$.

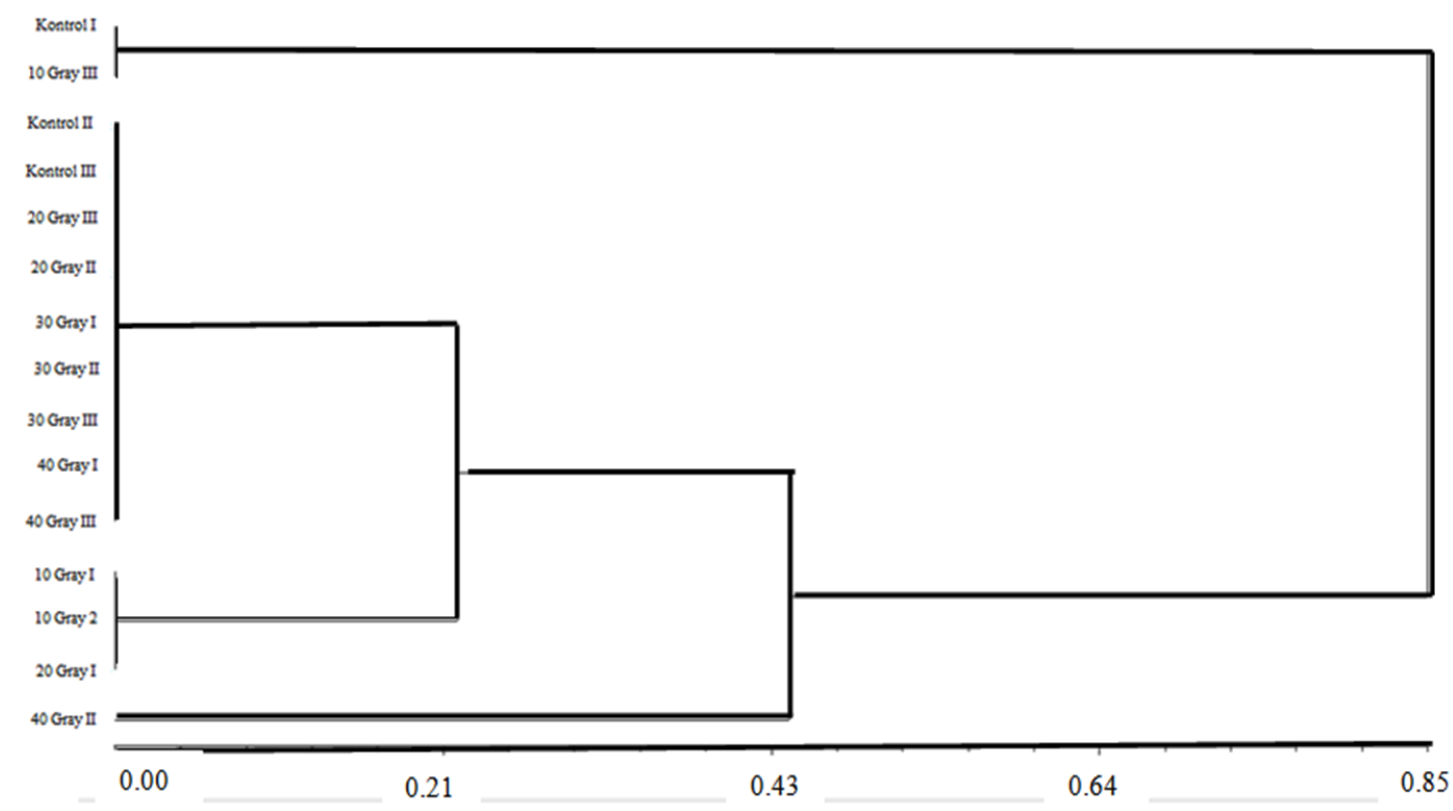

Figure 3 Dendrogram of genotypic characters of teak planlets of M1V1 Solomon clones. Individual treatment consists of Kontrol I: control replicated I; Kontrol II: control replicated II; Kontrol III: control replicated III; 10 gray I; 10 Gy replicated I; 10 Gy II: 10 Gy replicated II; 10 Gray III: 10 Gy replicated III; 20 gray I: 20 Gy replicated I; 20 gray II: 20 Gy replicated II; 20 gray III: 20 Gy replicated III; 30 gray I: 30 Gy replicated I; 30 
gray II: 30 Gy replicated II; 30 gray III: 30 Gy replicated III; 40 Gray I: 40 Gy replicated I; 40 Gray II: 40 Gy replicated II; 40 Gray III: 40 Gy replicated III;

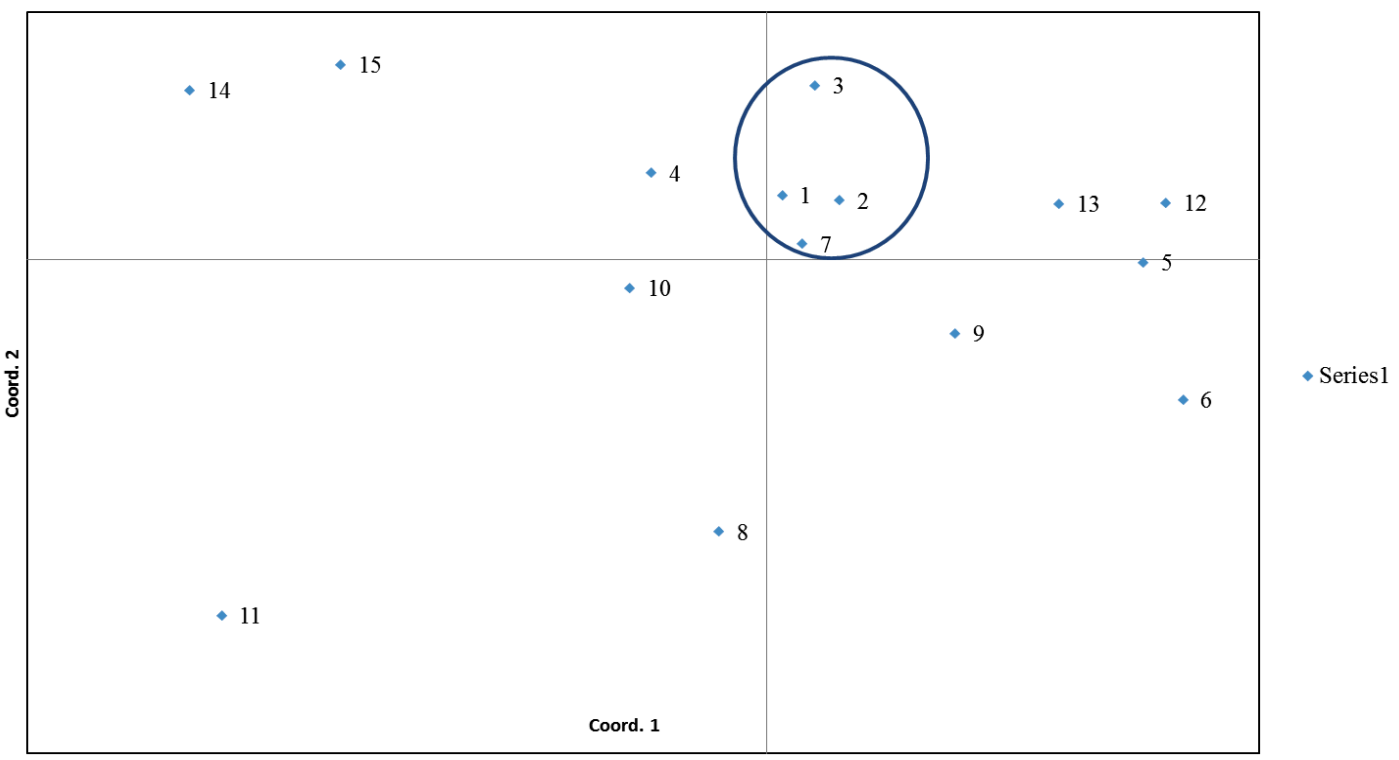

Figure 4 Analysis of principal coordinates analysis (PcoA) from 5 population (15 individual) of Salomon teak calli. Individual treatment including in $1=$ control replicated I; 2= Control replicated II; $3=$ control replicated III; $4=10$ Gy replicated I; $5=10$ Gy replicated II; $6=10$ Gy replicated II; $7=20$ Gy replicated I; $8=20$ Gy replicated II; 9= 20 Gy replicated III; $10=30$ Gy replicated I; 11= 30 Gy replicated II; $12=30$ Gy replicated III; $13=40$ Gy replicated I; $14=40$ Gy replicated II; $15=40$ Gy replicated III.

Based on the pattern, all individual control (I, II, and III) are clustered in quadrant 1 and formed their group, indicating a higher relationship. However, all mutant M1V1 scattered randomly throughout all quadrant sides (Figure 4); it has a great value of genetic distance, and the high level mutation relates to an extended heterogeneity. Mutants of irradiation dose at 10 Gy (I, II) and 20 (I, III) were a spacing adjacent to the control group (I, II, and III). It corresponded to the performance of irradiated planlets at 10 and $20 \mathrm{~Gy}$, it was a few growths normally. The similarity rate of mutants and control group showed the genetic relationship, the greater values distance of mutants to control have a closer the kinship relationship is. A variety of factors, including gene flow, inbreeding, and mutation, influence the level of genetic relationship [43].

Higher values of genetic similarity and lower values of genetic distance between individual treatments indicate higher mutation rates and lower heterogeneity. In both analyzes, dendrogram and PoCA, not all mutant M1V1 is clustered together. It may be caused by the differences of chromosome numbers in primers used and plant individual mutants [41]. The differences of clustering in both these analyses occur in bamboo [41] and teak [38].

In this study, mutant M1V1 teak has a higher genetic diversity average (H) (0.1391) compared to teak diversity in India (0.075) [25]. It means that irradiated on teak planlet in vitro mutagenesis has higher genetic variation than the population in India. So gamma ray is better to induce genetic variation than natural population. In plant cells, gamma rays have LET ((linear 
energy transfer) that can change the arrangement of nucleotide bases through ionization, dissociation, and excitation; which can methylate DNA from specific DNA damage (DDSs) and 64 pyrimidone photoproducts (64PPs) [35], [44].

Genetic diversity of mutant M1V1 maybe has potential lines and clones to select an effective parenting material for providing valuable information further genetic management and breeding programs aimed at improving the productivity and quality of the teak in the wood.

Table 3 Results of Analysis of Molecular Variance (AMOVA)

\begin{tabular}{lccccc}
\hline \multicolumn{1}{c}{ Source } & $\mathrm{DF}^{*}$ & $\mathrm{SS} *$ & $\mathrm{MS} *$ & $\mathrm{DE}^{*}$ & $\%$ \\
\hline $\begin{array}{l}\text { Among } \\
\text { treatments }\end{array}$ & 4 & 55.87 & 13.967 & 1.656 & $16 \%$ \\
$\begin{array}{l}\text { Within } \\
\text { treatments }\end{array}$ & 10 & 90.00 & 9.000 & 9.000 & $84 \%$ \\
\hline Total & 14 & 145.67 & & 10.66 & $100 \%$ \\
\hline
\end{tabular}

Notes: DF (Degrees of freedom); SS (Sum of squares); MS (Mean of squares); DE (Diversity Estimation)

AMOVA (Table 3) showed that genetic variation is within the treatment of gamma ray irradiation was $84 \%$ and $16 \%$ for among treatments. It means that genetic variation in mutant M1V1 generations was caused by the dominant effect of genetic material. This genetic material dominance may be caused by a combination of responses to tissue culture treatment and its genetic. Tissue culture is caused by putative mutations in plant cells due to the increased transposable element [45] and DNA methylation [46]. The transposable element and DNA methylation occurs in tissue culture, is caused by high concentrations of inorganic nutrients in the medium [47], repeated subcultures, mutagen agents (adenine sulfate) [48].

Mutant M1V1 must be had stable genetics, so it should be multiplicated and propagated vegetative treatment simultaneously both in vitro and in the field to eliminate chimera cells. The genetic distance between treatments was quite large, both among treatments and within treatments. Thus the gamma ray irradiation techniques on the teak planlet of Salomon clones could produce a high genetic diversity compared to the natural population.

\section{Acknowledgment}

The authors are highly thankful to the National Nuclear Energy Agency of Indonesia (BATAN) and Faculty of Forestry IPB University for providing insight and expertise that greatly assisted the research. We acknowledge with gratitude to the Faculty of Science and Technology (FST), Universitas Muhammadiyah Jambi for its continuing support to publication in this Journal.

\section{REFERENCES}

[1] Roshetko, J. M., Rohadi, D., Perdana, A., Sabastian, G., Nuryartono, N., Pramono, A. A., Widyani, N., Manalu, P., Fauzi, M.A., Sumardamto, P., Kusumowardhani, N. "Teak agroforestry systems for livelihood enhancement, industrial timber 
production, and environmental rehabilitation," Forests, Trees and Livelihoods, vol. 22, no. 2, pp. 241-256. 2013.

[2] Kollert, W., Jan Walotek. P. World teak resources, production, markets and trade. In: Kollert, W., Kleine, M. (ed.): The Global Teak Study Analysis, Evaluation and Future Potential of Teak Resources.Austria: IUFRO world series volume 36, pp. 83-90. 2017.

[3] Perum Perhutani. Perhutani 4.0+: connecting through connectivity Annual Report 2019, 2019.

[4] Dotaniya, M.L., Meena, V. D., Lata, M., Meena, H. P. "Teak plantation-a potential source of income generation," Popular Kheti vol. 1, no. 3, pp. 61-63. 2013.

[5] Rauf, S., Jaime, A., da Silva, T., Khan, A. A., Naveed, A. "Consequences of plant breeding on genetic diversity," International Journal of Plant Breeding vol. 4, no. 1, pp. 1-21. 2010.

[6] Iglesias-Andreu, L.G., Octavio-Aguilar, P., Bello-Bello, J. Current importance and potential use of low doses of gamma radiation in forest species. in: Adrovic F.(ed): Gamma Radiation. Mexico: In Tech Publishing. 2012.

[7] Sadono, R. "Determining growing space of Perhutani's teak plus plantation in Madiun, Saradan and Ngawi Forest District, East Java, Indonesia," Australian Journal of Basic and Applied Sciences vol. 8, no. 10, pp. 427-437. 2014.

[8] Bhargava, Y. R., Khalatkar. "Improve performance of tectona grandis seeeds with gamma irradiation [abstract]," International society for horticultural science 215. http://www.achaort.org. 1985.

[9] Sontikun, Y., Chanprame, S., Srinives, P., Chanprame, S. "Optimization of transient $\beta$-glucuronidase (gus) gene expression in teak (Tectona grandis L.f.) by Agrobacterium tumefaciens-mediated transformation system," J ISSAAS vol. 19, no. 2, pp. 49-57. 2013.

[10] Forster B. P., Shu, Q. Y. Plant mutagenesis in crop improvement: basic terms and applications. In: Shu Q.Y., Forster B.P., Nakagawa H. (ed). Plant Mutation Breeding and Biotechnology. Italy: CAB International and FAO, pp. 9-21. 2012.

[11] Hwang, J. E., Jang, D., Lee, K. J., Ahn, J., Kim, S. H., Kang, S., Kim, D.S., Kim, J. "Identification of gamma ray irradiation-induced mutations in membrane transport genes in a rice population by TILLING," Genes \& Genetic Systems vol. 91, no. 5, pp. 1-24. 2016.

[12] Caro-Melgarejo, D.P., Estupián-Rincón, S.Y., Rache-Cardenal, L.Y., PachecoMaldonado, J.S. "Effect of gamma rays on vegetative buds of Physalis peruviana L.," Acta Agronómica vol. 61, no. 4, pp. 277-285. 2012.

[13] Sreedhar., Anurag, C., Aparna, M. M., Pavan, D. K., Singal, R. K., Venu-Babu, P. "Influence of $\gamma$-radiation stress on scavenging enzyme activity and cell ultra structure in groundnut (Arachis hypogaea L.)," Pelagia Research Library, vol. 4, no. 2, pp. 35-44. 2013.

[14] RajaRamadoss, B., Ganesamurthy, K., Angappan, K., Gunasekaran, M. "Mutagenic effectiveness and efficiency of gamma rays in sesame (Sesamum indicum L.)," Global Journal of Molecular Sciences vol. 9, no. 1, pp. 01-06. 2014.

[15] Kadir, A. "Effects gamma ray irradiation on plants patchouli shoot," J. Agrivigor vol. 10, no. 2, pp. 177-127. 2011.

[16] Ohri, D., Kumar, A. "Nuclear DNA amounts in some tropical hardwoods," Caryologia vol. 9, no. 3-4, pp. 303-307. 1986.

[17] Witjaksono, Litz, R. E. "Effect of gamma irradiation on embryogenic Avocado cultures and somatic embryo development," Plant Cell, Tissue and Organ Culture vol. 77, pp. 139-140. 2004.

[18] Antony, T., Anees, P. M. W., Kumar, V., Sangamithra, D., Philp, T, Santhoshkumar, A. V. "Application of mercuric chloride and charcoal in micro-propagation of teak (Tectona grandis)," Indian Journal of Tropical Biodiversity vol. 23, no. 2, pp. 157166. 2015.

[19] Sheidai, M., Noormohammadi, Z., Shojaei-Jeshvaghani, F., Ghsemzadeh-Baraki, S., Farahani, F., Alishah, O. "Simple sequence repeat (SSR) and inter simple sequence repeat (ISSR) analyses of genetic diversity in tissue culture regenerated plants of cotton," African Journal of Biotechnology vol. 11, no. 56, pp. 11894-11900. 2012. 
[20] Datta, K. S. "Determiination of radiosensivity: prerequisite factor for induced mutagenesis," In: Malik P.C., Trivedi P.C. (ed) : Harnessing Plant Biotechnology and Physiology to Stimulate Agricultural Growth, India: Agrobios: 39-54. 2019.

[21] Quintana, V., Alvarado, L., Saravi, D., Borjas, R., Castro-Cepero, V., Julca-Otiniano, A., Gómez, A. "Gamma radiosensitivity of coffee (Coffea arabica L. var. typica)," Peruvian Journal of Agronomy vol. 3, no. 2, pp. 74-80. 2019

[22] Gupta, P. K., Nadgir, A, I., Mascaranhas, A. F., Jaganathan, V. "Tissue culture of forest trees: clonal multiplication of Tectona grandis L. (teak) by tissue culture," Plant Sci Lett vol. 17, pp. 259-268. 1980

[23] Walpole, R. E. Introduction to Statistics Third Edition, Jakarta, Gramedia Pustaka Utama, 1982.

[24] Anandan, R., Prakash, M., Deenadhayalan, T., Nivetha, R., Kumar, N. S. "Efficient invitro plant regeneration from cotyledon-derived callus cultures of Sesame (Sesamum indicum L.) and genetic analysis of true-to-type regenerants using RAPD and SSR markers," South African Journal of Botany vol. 119, pp. 244-251. 2018.

[25] Widyatmoko, A. Y .P .B. C., Rimbawanto, A., Chasani, A. R. "Genetic relationship among teak (Tectona grandis, Linn.f) populations based on RAPD (Random Amplifieds Polymorphic DNA) markers," Jurnal Pemuliaan Tanaman Hutan vol. 7, no. 3, pp. 151-166. 2013.

[26] Yasmin, K., Arulbalachandran, D. "Effect of gamma rays on morphological and quantitative traits of black gram (Vigna mungo (L.) Hepper) in M1 generation," Int. J. Cur. Tr. Res vol. 4, no. 2, pp. 5-15. 2016.

[27] Geras'kin, S., Evseeva, T., Oudalova, A. "Effects of long-term chronic exposure to radionuclides in plant populations," J Environ Radioact vol. 121, pp. 22-32. 2013.

[28] Akshatha, Chandrashekar, K. R, Somashekarappa, H. M., Souframanien, J. "Effect of gamma irradiation on germination, growth, and biochemical parameters of Terminalia arjuna Roxb," Radiation and Environ vol. 36, no. 1, pp. 38-44. 2013.

[29] Borzouei, A., Kafi, M., Khazaei, H., Naseriyan, B., Majdabadi, A. "Effects of gamma radiation on germination and physiological aspects of wheat (Triticum aestivum L.) seedlings," Pak. J. Bot vol. 4, no. 2, pp. 2281-2290. 2010.

[30] Mosllem, S., Behbahani, M., Mousavi, E. S. "Effect of gamma radiation on callus induction and regeneration of Rosa canina through in vitro culture," Trakia Journal of Sciences vol. 11, no. 2, pp. 158-162. 2012.

[31] Basha, M. H., Mehta, A. K., Gour, V. K., Kachare, S. "Biological effects of gamma irradiation in oat (Avena sativa L.)," Range Mgmt. \& Agroforestry vol. 36, no. 1, pp. 60-65. 2015.

[32] Chanchula, N., Taychasinpitak, T., Jala, A., Thanananta, T., Kikuchi, S. "Radiosensitivity of in vitro cultured Torenia fournieri Lind. from Thailand by $\gamma$ ray irradiation," Int Trans J Eng Manag Sci Tech vol. 6, no. 4, pp. 157-164. 2015.

[33] Galván, I., Bonisoli-Alquati, A., Jenkinson, S., Ghanem, G., Wakamatsu, K., Mousseau, T., Møller, A. "Chronic exposure to low-dose radiation at Chernobyl favours adap tation to oxidative stress in birds," Funct. Ecol. vol. 28, pp. 13871403. 2014.

[34] Thakur, R.C., Ishii, K. "Detection and fingerprinting of narrow-leaf mutants in micropropagated hybrid poplar (Populus sieboldii x $P$ grandidentata) using random amplified polymorphic DNA," International Journal of Farm Sciences, vol. 2, no. 1, 79-84. 2012.

[35] Minisi, A. F., El-Mahrouk, E., Rida, F. M., Nasr, M. "Effect of gamma radiation on germination, growth characristics and marphological variation of Molluccella leavis L.," American-Eurasian J Agric \& Environ Sci vol. 13, no. 5, pp. 696-704. 2013.

[36] Rastogi, J., Siddhant., Bubber P., Lal., Sharma, B. "Somaclonal variation: a new dimension for Sugarcane improvement," GERF Bulletin of Biosciences vol. 6, no. 1, pp. 5-10. 2015.

[37] Yaycili, O., Alikamanoğlu, S. "Induction of salt-tolerant potato (Solanum tuberosum L.) mutants with gamma irradiation and characterization of genetic variations via RAPD-PCR analysis," Turk J Biol vol. 36, pp. 405-412. 2012. 
[38] Chaudhari, C., Jha, S. K., Dhaka, R. K., Parekh, V., Sankanur, M.S., Prajapat, P., Thakur, S. "Genetic diversity analysis of teak in South Gujarat by RAPD marker," International Journal of Chemical Studies vol. 6, no. 6, pp. 260-267. 2018.

[39] Thuy, M. T P., Ha, T. T. T., Quang, T. H. "Analysis of genetic diversity in Pa Co pine (Pinus kwangtungensis Chun ex Tsiang) using RAPD and ISSR markers," Biotechnologyvol vol. 62, no. 1, pp. 62-68. 2020.

[40] Kumar, S., Kumar, M., Yadav, H. K., Sharma, S., Kumar, S. "Genetic diversity and population structure analysis of Chrysanthemum (Dendranthema grandiflora Tzvelev) germplasm based on RAPD marker," Journal of Environmental Biology vol. 38, pp. 457-464. 2017.

[41] Annisa, Hafzari, R., Setiawati, T., Irawan, B., Kusmoro, J. "Evaluation of RAPD markers for molecular identification of five bamboo genera from Indonesia," Folia Forestalia Polonica, Series A - Forestry vol. 61, no. 4, pp. 255-266. 2019.

[42] Amom, T., Tikendra, L., Apana, N., Goutam M., Sonia, P., Koijam, A. S., Potshangbam, A. M., Rahaman, H., Nongdam, P. "Efficiency of RAPD, ISSR, iPBS, SCoT and phytochemical markers in the genetic relationship study of five native and economical important bamboos of North-East India," Phytochemistry vol. 174, p 112330. 2020.

[43] Nadeem, M. A., Nawaz, M. A., Shahid, M. Q., Dogan, Y., Comertpay, G., Yildiz, M., Hatipoglu, R., Ahmad, F., Alsaleh, A., Labhane, N., Ozkan, H., Chung, G., Baloch, F. S. "DNA molecular markers in plant breeding: current status and recent advancements in genomic selection and genome editing," Biotechnology and Biotechnological Equipment, vol. 32, no. 2, pp. 261-285. 2017.

[44] Ikehata, H., Ono, T. "The mechanisms of UV mutagenesis," J Radiat Res vol. 52, pp. 115-125. 2011

[45] Azman, S. A., Corinne, M., Grandbastien, M. A., Tam. M, S. "Transposable elements and the detection of somaclonal variation in plant tissue culture: A review," Malaysian Applied Biology vol. 43, no. 1, pp. 1-12. 2014.

[46] Stelpflug, S. C., Eichten, S. R., Hermanson, P. J., Springer, N. M., Kaeppler, S. M. "Consistent and heritable alterations of DNA methylation are induced by tissue culture in maize," Genetics vol. 198, pp. 209-218. 2014.

[47] Reed, B. M., Wada, S., DeNoma, J., Niedz, R. "Mineral nutrition influences physiological responses of pear in vitro," In Vitro Cellular \& Developmental Biology - Plant vol. 49, no. 6, pp. 699-709. 2013.

[48] Sharma, V., Kamal, B., Srivastava, N., Dobriyal, A. K., Jadon, V. S. "Effects of additives in shoot multiplication and genetic validation in Swertica chirayita revealed through rapd analysis," Plant Tissue Cult \& Biotech vol. 23, no. 1, pp. 1119. 2013. 